\title{
Use of hydrological methods for assessment of environmental flow in a river reach
}

\author{
S. Shaeri Karimi $\cdot$ M. Yasi $\cdot$ S. Eslamian
}

Received: 11 August 2010/Revised: 15 October 2011/Accepted: 23 November 2011/Published online: 20 April 2012

(C) CEERS, IAU 2012

\begin{abstract}
Environmental flow assessment and maintenance are relatively new practices, especially in developing countries. This paper describes the desktop assessment of environmental flows in a river with insufficient data on ecological features and values. In this study, the potential environmental flows in a typical river reach of the Shahr Chai River in Iran were investigated using a newly developed hydrological method (flow duration curve (FDC) shifting) and Global Environmental Flow Calculator software. This approach uses monthly flow data to develop an environmental FDC and to generate flow requirements corresponding to different features of the river ecosystem. Results were compared with those from four alternative hydrological methods: the desktop reserve model (DRM), Tennant, low-flow index, and flow duration curve analysis (FDCA). Comparisons of these methods indicated that to maintain the basic function of the river ecosystem, the river flows should be managed within an acceptable environmental level. The predictions from the Tennant method and the low-flow index (7-day low flow with a 10-year return period), and from the FDCA (for flows exceeding $90 \%$ of
\end{abstract}

S. Shaeri Karimi $(\bowtie)$

Young Researchers Club, Khorasgan Branch,

Islamic Azad University, Isfahan, Iran

e-mail: sarashaeri@yahoo.com

M. Yasi

Department of Water Engineering,

Urmia University, Urmia, Iran

S. Eslamian

Department of Water Engineering,

Isfahan University of Technology,

P. O. Box: 8415683111, Isfahan, Iran occurrence) are not as reliable as those from the FDC shifting technique and DRM. Comparative results indicate that a minimum flow rate of $1.2 \mathrm{~m}^{3} / \mathrm{s}$ (equivalent to $23 \%$ of the natural mean annual runoff, or flow with $80 \%$ occurrence depicted from the FDC) is required for the Shahr Chai River to run toward the internationally recognized Urmia Lake in Iran.

Keywords Desktop reserve model - Ecological management classes - Flow duration curve shifting . Flow indices - Mean annual runoff

\section{Introduction}

Water is an important part of any ecosystem, both qualitatively and quantitatively. Reduced water quantity and deteriorated water quality have serious negative impacts on ecosystems. The environment has a natural self-cleaning capacity and resilience to water shortages, but when these processes are inhibited, biodiversity is lost, livelihoods are affected, natural food sources (e.g., fish) are damaged, and high cleanup and rehabilitation costs are incurred (IWMI 2004).

The flows of the world's rivers are increasingly being modified through impoundments such as dams and weirs, extractions for agriculture and urban supplies, maintenance of flows for navigation, drainage return flows, and structures for flood control. These interventions have had significant negative environmental effects by reducing the total flow of many rivers and altering both the seasonality of flows and the size and frequency of floods. Therefore, the modification of river flows for human needs must be balanced with the maintenance of essential water-dependent ecological needs (Davis and Hirji 2003). 
Water that is allocated for maintaining aquatic habitats and ecological processes in a desirable state is referred to as "instream flow requirement (IFR)", "environmental flow (EF)", "environmental flow requirement (EFR)", or "environmental water demand (EWD)"; the process for determining these flows is referred to as "environmental flow assessment (EFA)" (Davis and Hirji 2003; Dyson et al. 2003; Lankford 2002; Smakhtin et al. 2004).

More than 200 methods were identified for the evaluation of EFA in 44 different countries (Tharme 2003). These methods are grouped into four categories: hydrological, hydraulic rating, habitat simulation, and holistic. Concepts and details of these methods are presented in the literature (Acreman and Dunbar 2004; Jowett 1997; Tharme 2003).

Hydrological methods have been developed for broadscale planning and make use of readily available streamflow data alone. Among these and the best known is the Tennant method, developed in the USA, which identifies various levels of minimum flows based on specified proportions of the mean flow (Tennant 1976). More recently, the range of variability approach (RVA) is a sophisticated hydrological method which evaluates flow regimes based on a comparison of 33 flow statistics for the regulated and natural flow regime (Richter et al. 1996, 1997, 1998).

Considering the differences among ecosystem structures, EFR studies have been conducted for rivers, wetlands, estuaries, forest and grassland ecosystem (Arthington et al. 2003; Kashaigili et al. 2005, 2007; King and Brown 2006; Sun et al. 2008; Yang et al. 2009).

A parsimonious model was developed for assessing ecologically significant flood dynamics of floodplain wetlands (Powell et al. 2008). The development and calibration of this model remains a challenge because of the lack of available data.

A new framework termed "the ecological limits of hydrologic alteration (ELOHA)" was developed (Poff et al. 2010). This model is a synthesis of a number of existing hydrologic techniques and EFA methods that are currently being used to various degrees and that can support comprehensive regional flow management.

Chen and Zhao (2011) combined a hydrological model with a water balance model and remote sensing data to evaluate ecosystem responses to the changing EFs of the Wolonghu Wetland.

Different EFA methods are used for different purposes. The decision to use a specific method depends on different factors such as the followings (HR Wallingford 2003):

- Type of river (e.g., perennial, seasonal, high base flow, flashy);

- Perceived environmental importance;

- Complexity of the decision to be made;
- Increased cost and difficulty of collecting large amounts of information; and

- Severity of different resource developments.

Regardless of the type of EFA, the methods have been designed and/or applied in a developed country context. Distinct gaps in EF knowledge and practice are evident in current approaches to water resources management in almost all of the developing countries. The lack of technical and institutional capacity to establish environmental water allocation is a major challenge in protecting river ecosystems in developing countries (Tharme and Smakhtin 2003).

The main goal of the present study was to conduct a desktop assessment of EFs in a typical river reach in Iran. The potential EFs in the river reach were evaluated using a newly developed hydrological method known as flow duration curve shifting (FDC shifting) and Global Environmental Flow Calculator (GEFC) software. The results were compared with four other hydrological methods: desktop reserve model (DRM), Tennant, low-flow index defined as 7-day low flow with a 10 -year return period (7Q10), and flow duration curve analysis (FDCA). The present study was carried out in the Department of Water Engineering of the Urmia University in 2010.

\section{Materials and methods}

\section{Study area}

The Shahr Chai River catchment covers an area of about $753 \mathrm{~km}^{2}$ and is part of the Urmia Lake basin $\left(37^{\circ} 35^{\prime}-\right.$ $\left.37^{\circ} 36^{\prime} \mathrm{N}, 45^{\circ} 00^{\prime}-45^{\circ} 16^{\prime} \mathrm{E}\right)$, located in the West Azerbaijan province, northwest of Iran. The mean annual air temperature of the basin is about $11^{\circ} \mathrm{C}$ and ranges from $-7{ }^{\circ} \mathrm{C}$ (in January) to $+31{ }^{\circ} \mathrm{C}$ (in July). Average annual precipitation is $354 \mathrm{~mm}$ and occurs mostly between March and April. Annual potential evapo-transpiration is about $1,200 \mathrm{~mm}$, more than three times the amount of precipitation. The climate of the river basin is semiarid and cold.

The Shahr Chai River is $60.5 \mathrm{~km}$ long and flows from the Zagros mountain range (which forms the border line between Iran and Turkey), past the city of Urmia, and into the Urmia Lake (the largest inland lake in Iran). Urmia Lake is an internationally recognized and registered ecosystem, and its environmental values depend largely on the inflow of river water (such as from the Shahr Chai River). Shahr Chai River restoration is a major practice along the waterway, not only for ecological and recreational purposes but also for the rehabilitation of the Urmia Lake as its receiving water. This lake currently suffers from serious 
degradation and damages to the local and international environment.

Three gauging stations are located along the Shahr Chai River. Of these three stations, the Band gauging station was selected to represent the potential inflows to the main stream of the river. A reservoir (Shahr Chai Dam) was constructed upstream of the Band gauging station in 2005. As the natural hydrological regime is to be related to the ecological rehabilitation of a river system, mean daily and monthly flow data collected over 55 years (between 1949 and 2004) were considered to eliminate the effect of reservoir operation on the natural flow regime of the Shahr Chai River downstream.

\section{Methods}

In this study, with the lack of ecological information, five different hydrological methods were used to evaluate $\mathrm{EF}$ in the Shahr Chai River. The basis of the hypothesis of this study is that a hydrological regime can be related to the ecological condition of a river system (Hughes and Hannart 2003; Naiman et al. 2002; Richter et al. 1997; Smakhtin and Anputhas 2006; Smakhtin et al. 2006). The main features of these methods are described in the following.

\section{FDC shifting method}

The FDC shifting method is a new hydrological method developed by Smakhtin and Anputhas (2006). The method uses monthly flow data and is built around a period-ofrecord FDC. This method includes four subsequent steps to evaluate EF, as follows:

Step 1: Simulating reference hydrological conditions. The first step is the calculation of a representative FDC for a desired river reach using a monthly time series. All FDCs in this method are represented by a table of flows corresponding to 17 fixed percentage points: $0.01,0.1,1,5,10$, $20,30,40,50,60,70,80,90,95,99,99.9$, and $99.99 \%$. These points (1) ensure that the entire flow range is adequately covered, and (2) are easy to use in the context of Steps 2 through 4.

Step 2: Defining environmental management classes $(E M C s)$. The purpose of determining $\mathrm{EF}$ is to maintain or upgrade an ecosystem to some prescribed or negotiated condition, also referred to as desired future state, EMC, ecological management category, and level of environmental protection. Higher EMCs require a higher allocation of water for ecosystem maintenance or conservation and a higher preservation of flow variability. Ideally, EMCs should be based on empirical relationships between flow and ecological conditions associated with clearly identifiable thresholds. However, evidence for such thresholds is insufficient so far, and these categories are a management concept. Six EMCs are used in this method and are presented in Table 1. The EMCs (Table 1) are similar to those described in DWAF (1997).

Table 1 Environmental management classes (EMCs) used in the FDC shifting method (Smakhtin and Anputhas 2006)

\begin{tabular}{|c|c|c|}
\hline EMC & Most likely ecological condition & Management perspective \\
\hline A (natural) & $\begin{array}{l}\text { Natural rivers with minor modification of instream and } \\
\text { riparian habitat }\end{array}$ & $\begin{array}{l}\text { Protected rivers and basins; reserves and national parks; no } \\
\text { new water projects (dams, diversions) allowed }\end{array}$ \\
\hline $\begin{array}{l}\text { B (slightly } \\
\text { modified) }\end{array}$ & $\begin{array}{l}\text { Slightly modified and/or ecologically important rivers with } \\
\text { largely intact biodiversity and habitats despite water } \\
\text { resources development and/or basin modifications }\end{array}$ & $\begin{array}{l}\text { Water supply schemes or irrigation development present and/ } \\
\text { or allowed }\end{array}$ \\
\hline $\begin{array}{l}\mathrm{C} \text { (moderately } \\
\text { modified) }\end{array}$ & $\begin{array}{l}\text { The habitats and dynamics of the biota have been disturbed, } \\
\text { but basic ecosystem functions are still intact; some sensitive } \\
\text { species are lost and/or reduced in extent; alien species } \\
\text { present }\end{array}$ & $\begin{array}{l}\text { Multiple disturbances (e.g., dams, diversions, habitat } \\
\text { modification, and reduced water quality) associated with the } \\
\text { need for socioeconomic development }\end{array}$ \\
\hline $\begin{array}{l}\mathrm{D} \text { (largely } \\
\text { modified) }\end{array}$ & $\begin{array}{l}\text { Large changes in natural habitat, biota, and basic ecosystem } \\
\text { functions have occurred; species richness is clearly lower } \\
\text { than expected; much lowered presence of intolerant species; } \\
\text { alien species prevail }\end{array}$ & $\begin{array}{l}\text { Significant and clearly visible disturbances (including dams, } \\
\text { diversions, transfers, habitat modification, and water quality } \\
\text { degradation) associated with basin and water resources } \\
\text { development }\end{array}$ \\
\hline $\begin{array}{l}\text { E (seriously } \\
\text { modified) }\end{array}$ & $\begin{array}{l}\text { Habitat diversity and availability have declined; species } \\
\text { richness is strikingly lower than expected; only tolerant } \\
\text { species remain; indigenous species can no longer breed; } \\
\text { alien species have invaded the ecosystem }\end{array}$ & $\begin{array}{l}\text { High human population density and extensive water resources } \\
\text { exploitation; generally, this status should not be acceptable } \\
\text { as a management goal; management interventions are } \\
\text { necessary to restore flow pattern and to "move" a river to a } \\
\text { higher management category }\end{array}$ \\
\hline $\begin{array}{l}\mathrm{F} \text { (Critically } \\
\text { modified) }\end{array}$ & $\begin{array}{l}\text { Modifications have reached a critical level; ecosystem has } \\
\text { been completely modified with almost total loss of natural } \\
\text { habitat and biota; in the worst case, basic ecosystem } \\
\text { functions have been destroyed and changes are irreversible }\end{array}$ & $\begin{array}{l}\text { This status is not acceptable from the management } \\
\text { perspective; management interventions are necessary to } \\
\text { restore flow pattern and river habitats (if still possible/ } \\
\text { feasible) to "move" a river to a higher management category }\end{array}$ \\
\hline
\end{tabular}


Fig. 1 Estimation of environmental FDCs for different EMCs by lateral shift (Smakhtin and Anputhas 2006)

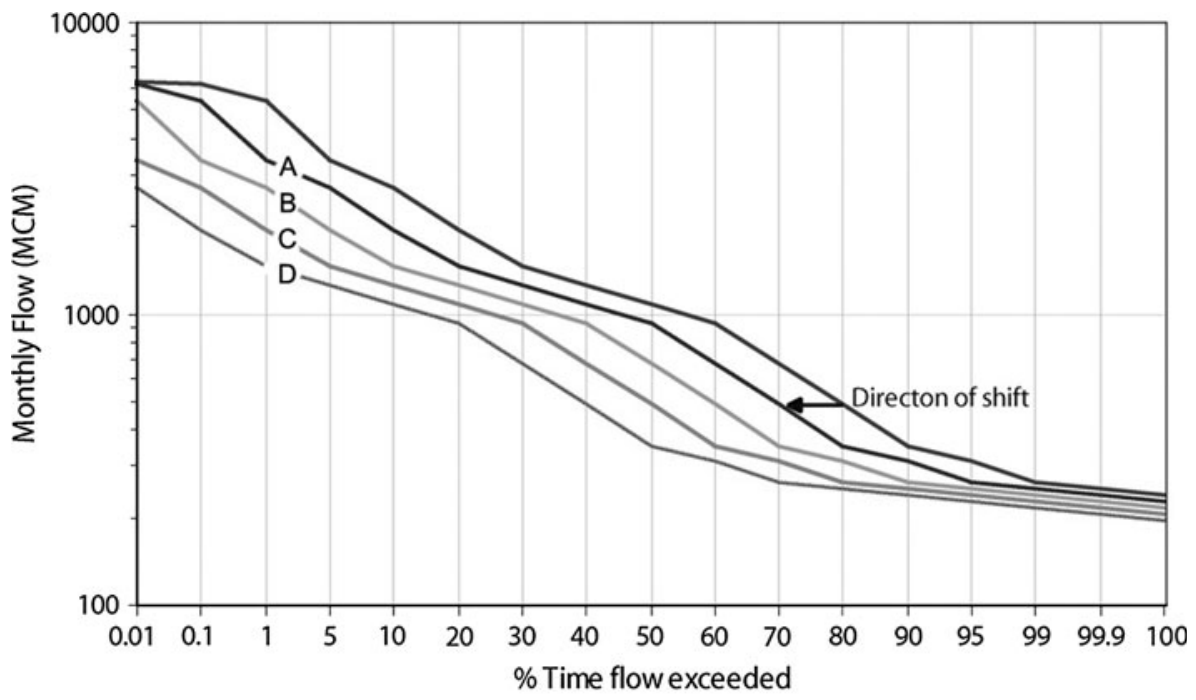

- Reference FDC Class A Class B Class C Class D
Step 3: Establishing environmental FDCs from reference condition. A simple approach proposed by Smakhtin and Anputhas (2006) determines the default FDC that summarizes EF for each EMC. These curves are determined by the lateral shift of the original reference FDC, i.e., to the left along the probability axis. The 17 percentage points on the probability axis (Step 1) are used as steps in this shifting procedure. An FDC shift by one step means that a flow that was exceeded $99.99 \%$ of the time in the original FDC will now be exceeded $99.9 \%$ of the time, the flow at $99.9 \%$ becomes the flow at $99 \%$, the flow at $99 \%$ becomes the flow at $95 \%$, etc. The procedure is graphed in Fig. 1. A linear extrapolation is used to define the revised low flows at the lower tail of a shifted curve.

The difference between the default shifts of the reference FDC for different EMCs is set to the 1 percentage point category. In other words, a minimum lateral shift of one step (distance between two adjacent percentage points in the FDC table) is used. This means that for an A-class river, the default environmental FDC is determined by the original reference FDC shifted 1 step to the left along the probability axis. For a B-class river, the default environmental FDC is determined by the original reference FDC shifted two steps to the left along the probability axis from its original position, etc.

Step 4: Simulating continuous monthly time series of $E F s$. An environmental FDC for any EMC gives only a summary of the EF regime acceptable for this EMC. However, once such a curve is determined, as described above, it may also be converted into an actual environmental monthly flow time series. The spatial interpolation procedure described in detail by Hughes and Smakhtin
(1996) can be used for this purpose. In this method, for each month, the procedure follows: (1) to identify the percentage point position of the natural stream flow on the natural flow's period-of-record FDC, and (2) to read off the monthly flow value for the equivalent percentage point from the environmental FDC (Fig. 2). Generation of the EF time series completes the desktop EF estimation for a site.

Mean annual environmental runoff (MAER) using an EF time series is calculated in the same manner as mean annual runoff (MAR) using the original time series. Dividing the first value by the second value (MAER/MAR) gives the percentage of MAR in each EMC.

\section{GEFC software}

GEFC is a free software package developed by the International Water Management Institute (IWMI), Sri Lanka, in collaboration with the Water Systems Analysis Group of the University of New Hampshire, for desktop assessments of EFRs in river basins (Smakhtin and Eriyagama 2008). GEFC is coded in Visual Basic 2005 and uses the FDC shifting technique to estimate EF. In this study, GEFC (ver. 1) was used to analyze the data and estimate EFR.

\section{DRM method}

Desktop reserve model is a hydrology-based, planning-type EFA methodology developed in South Africa by Hughes and Hannart (2003). This model is built on the concepts of the building block method and is widely recognized as a scientifically legitimate approach to setting EFRs. 


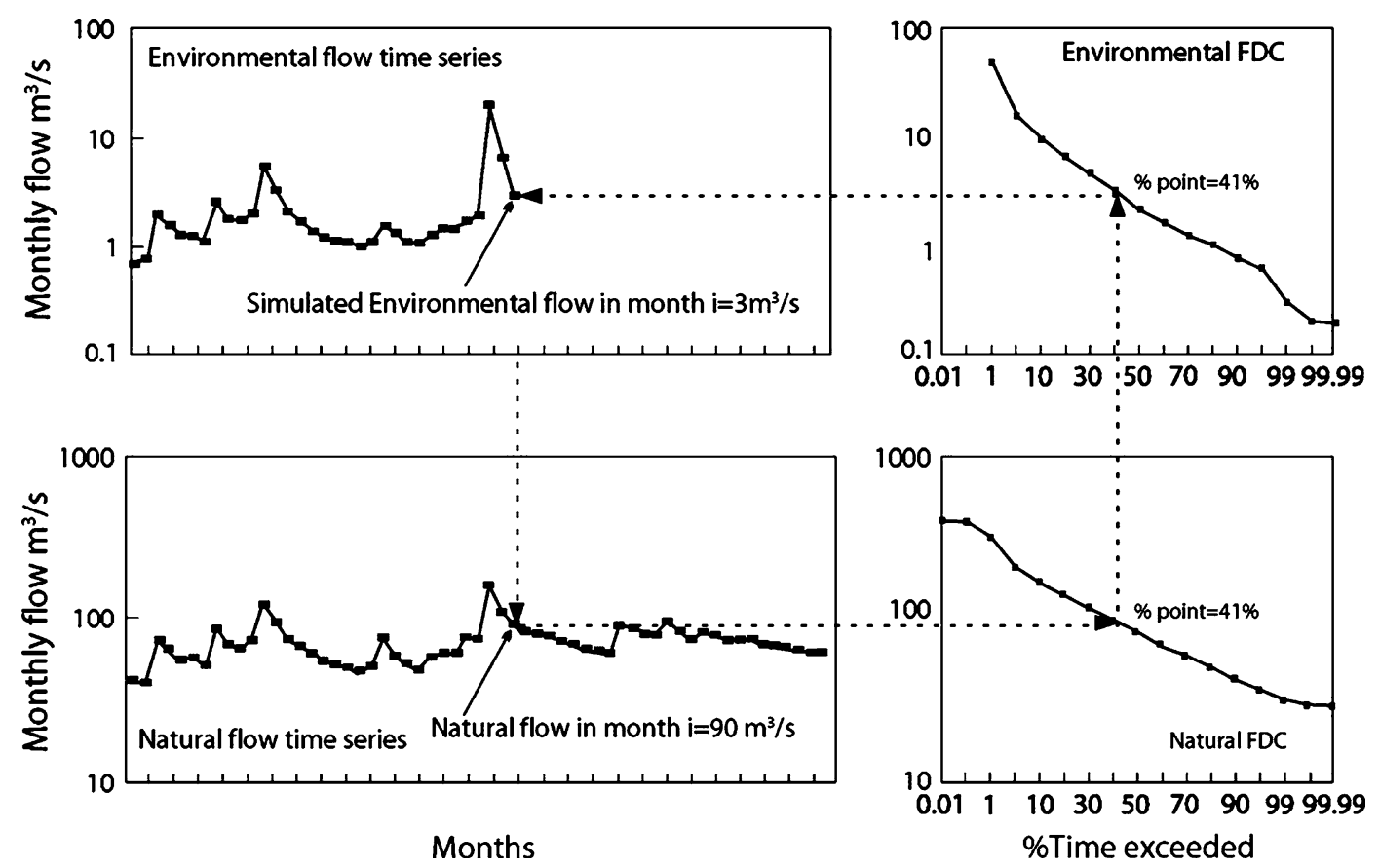

Fig. 2 Illustration of the transformation procedure to generate a complete monthly time series of EF from the established environmental FDC (Smakhtin and Eriyagama 2008)

The Hughes and Hannart method assumes that EFR decreases with increasing flow variability and increases with increasing base flow contribution. The average of (1) the coefficient of variation of monthly flows during the three wet-season months (January-March) and (2) the coefficient of monthly flows during the three dry-season months (September-November) is used as a measure of flow variability. This average is then divided by the base flow index (BFI) to give an index CVB, which Hughes and Hannart used to predict EFRs. The predicted EFRs are expressed as percentages of MAR, which in this study will be estimated using flow data from stations without significant abstractions or impoundments. Separate equations were developed by Hughes and Hannart for predicting the proportion of lows flows and high flows that should constitute EFRs. The following equation was derived to reflect that low-flow EFRs (MLIFR) decrease within increasing flow variability $(\mathrm{CVB})$ :

MLIFR $=\mathrm{LP} 4+\frac{(\mathrm{LP} 1 \times \mathrm{LP} 2)}{\left(\mathrm{CVB}^{\mathrm{LP} 3}\right)^{1-\mathrm{LP} 1}}$

where MLIFR is the low-flow EFR as a percentage of the MAR, and LP1, LP2, LP3, and LP4 are parameters whose values depend on the desired EMC.

In semiarid regions, most of the high flows are due to isolated events, which increase the variability of flows. Hughes and Hannart therefore assumed that the EFR for high flows increases with increasing flow variability (CVB) and derived Eqs. (2) and (3) for estimating high-flow EFR (MHIFR) as a proportion of MAR.

$$
\begin{aligned}
& \text { MHIFR }=\gamma \times \mathrm{HP} 2+\mathrm{HP} 3 \\
& \text { If CVB }>15 \text { then } \\
& \text { MHIFR }=(\gamma \times \mathrm{HP} 2+\mathrm{HP} 3)+(\mathrm{CVB}-15) \times \mathrm{HP} 4
\end{aligned}
$$

The DRM parameters have been determined empirically for South African rivers, and DRM parameter values must be modified for other conditions. In computing the results, the model assumes that the primary dry-season months are June to August and the primary wet season months are January to March, as occurs over much of South Africa. This assumption cannot be altered within the model. However, for the Shahr Chai River, the key months are April to June and September to November for the wet and dry seasons, respectively. To reflect these key months, the input data were shifted by 3 months (i.e., January became April and so forth) and the results were then readjusted.

\section{Tennant method}

The Tennant (or Montana) method developed by Tennant (1976) is the most common hydrological method applied worldwide and has been used by at least 25 countries (Tharme 2003). This method is based on empirical relationships between the specified percent of the MAR and the prescribed ecological condition of the river. The Tennant method uses a percentage of the MAR for two different 
Table 2 The Tennant (Montana) method (1976)

\begin{tabular}{lll}
\hline Description of flows & \multicolumn{2}{l}{$\begin{array}{l}\text { Recommended base flow regimens (percent } \\
\text { of mean annual runoff) }\end{array}$} \\
\cline { 2 - 3 } & October-March & April-September \\
\hline Flushing or maximum & 200 & 200 \\
Optimum range & $60-100$ & $60-100$ \\
Outstanding & 40 & 60 \\
Excellent & 30 & 50 \\
Good & 20 & 40 \\
Fair or degrading & 10 & 30 \\
Poor or minimum & 10 & 10 \\
Severe degradation & $<10$ & $<10$ \\
\hline
\end{tabular}

6-month periods to define conditions of flow related to fishery, wildlife, recreational, and environmental resources (Table 2).

Low-flow index method

The low-flow index is interpreted as the 7-day low flow with a 10-year return period (7Q10), using daily discharge data from the river reach under study. The 7 Q10 flow is the second most widely used hydrological method for the evaluation of EF (Tharme 2003). This flow rate is considered to be the minimum EFR throughout the year.

\section{FDCA method}

Another common hydrology-based methodology applied worldwide in its general form is the FDCA method. Smakhtin (2001) indicated that the design low-flow range of an FDC ranges between 70 and $99 \%$ (denoted as Q70 and Q99 \%, respectively). The Q90 and Q95\% are frequently used as indicators of low flow and have been widely used to set minimum EFs (Pyrce 2004).

\section{Results and discussion}

The potential EFs in the river were evaluated by newly developed hydrological method (FDC shifting) using GEFC (ver. 1) software. Monthly flow data collected over 55 years (between 1949 and 2004) were used to develop an FDC and to generate flow requirements corresponding to different levels of river ecosystem values.

Figure 3 shows the development of FDCs corresponding to six different EMCs (A to F) at the Band gauging station in the river.

Estimation of the long-term EFs as percent of natural MAR for different EMCs of the river is presented in Table 3 using the FDC shifting method. The corresponding EFs clearly decrease progressively as ecosystem protection decreases. The results indicate that much more than $10 \%$ of the mean annual runoff rate (i.e., $10 \%$ of $5.2 \mathrm{~m}^{3} / \mathrm{s}$ ) must be allocated to maintain river life and that less that $10 \%$
Fig. 3 Environmental FDCs for different EMCs (A to F), Shahr Chai River

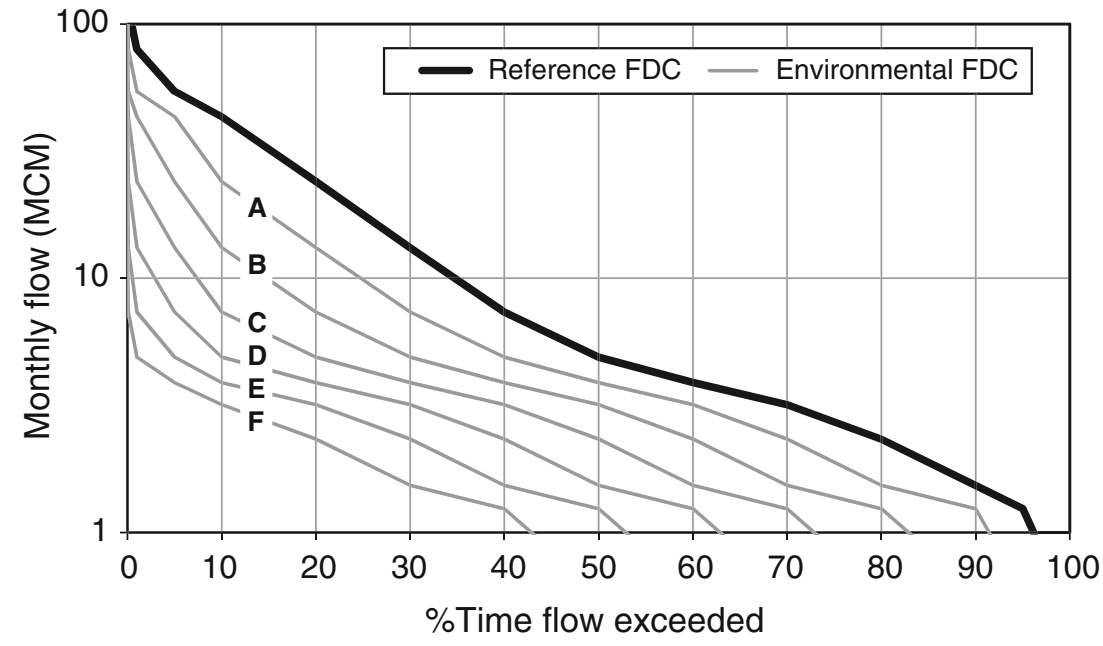

Table 3 Estimation of EF as percent of MAR for different EMCs using the FDC shifting method, Shahr Chai River

\begin{tabular}{|c|c|c|c|c|c|c|c|c|}
\hline \multirow[t]{2}{*}{ Station } & \multirow[t]{2}{*}{ Record period } & \multirow[t]{2}{*}{$\operatorname{MAR}\left(\mathrm{m}^{3} / \mathrm{s}\right)$} & \multicolumn{6}{|c|}{ Long-term EF (\% of MAR) at different EMCs } \\
\hline & & & Class A & Class B & Class C & Class D & Class E & Class $\mathrm{F}$ \\
\hline Band & 1949-2004 & 5.2 & 68.8 & 44.1 & 28.2 & 18.9 & 13.4 & 10 \\
\hline
\end{tabular}


Table 4 Estimation of EF as percent of MAR for different EMCs using the DRM, Shahr Chai River

\begin{tabular}{lllllll}
\hline Station & Record period & MAR $\left(\mathrm{m}^{3} / \mathrm{s}\right)$ & \multicolumn{3}{l}{ Long-term EF $(\%$ of MAR) at different EMCs } \\
\cline { 3 - 7 } & & Class A & Class B & Class C & Class D \\
\hline Band & $1949-2004$ & 5.2 & 53.8 & 35.6 & 23.2 & 15.0 \\
\hline
\end{tabular}

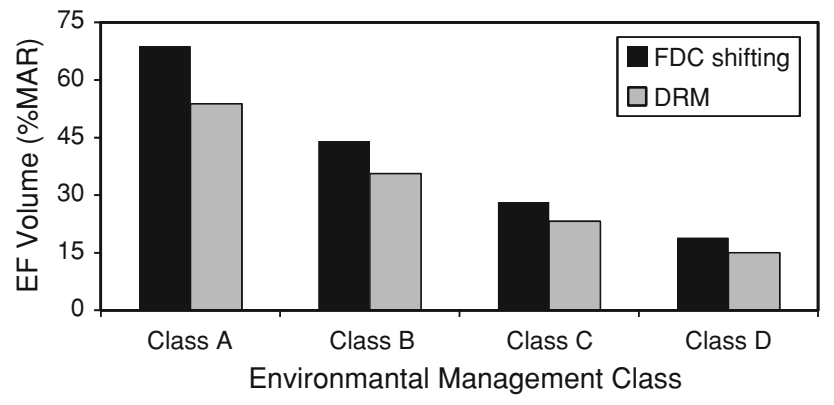

Fig. 4 Comparison of EFRs estimated from FDC shifting method and DRM in different environmental classes, Shahr Chai River

would characterize the river as a dead environment. An average annual EF allocation of $1.5 \mathrm{~m}^{3} / \mathrm{s}$ (equivalent to $28 \%$ of natural MAR) is expected for maintaining the basic function of the river ecosystem (i.e., the Class $\mathrm{C}$ condition in Table 1).

The EF evaluation from the FDC shifting method was compared with four other hydrological methods: DRM, Tennant method, 7Q10 index method, and FDC indices (Q70 to Q95).

Table 4 presents the estimated EFs from the DRM method. Comparative results from the FDC shifting and DRM methods are shown in Fig. 4. Since the E and F classes are environmentally unacceptable (Table 1), they are not included in Table 4 and Fig. 4.

The estimation from the FDC shifting method is consistently more conservative than the DRM method. The systematic underestimation of EFs from the DRM method could be related to necessary modifications of the empirical parameters used in the DRM. Currently, there are no scientific grounds (in terms of ecology, geomorphology, and hydraulic fields) for any such changes in the modeling of the Shahr Chai River ecosystem. The DRM results indicate that an average annual environmental flow allocation of $1.2 \mathrm{~m}^{3} / \mathrm{s}$ (equivalent to $23 \%$ of natural MAR) is required for maintaining the river ecosystem within the Class $\mathrm{C}$ condition in Table 1 (20\% underestimation compared with $1.5 \mathrm{~m}^{3} / \mathrm{s}$ from the FDC shifting method).

It is possible to produce actual monthly EF distribution in the following three methods: FDC shifting, DRM and
Tennant method. For better comparison, the monthly results of these three methods are shown in Fig. 5.

Table 5 presents the computational results of the EFR from the five hydrological methods (i.e., FDC shifting, DRM, Tennant, 7Q10, and FDCA, Q70 to Q95 \%) for the river.

Using the Tennant method and based on national legislation, $10 \%$ of the MAR (equivalent to $0.5 \mathrm{~m}^{3} / \mathrm{s}$ ) for the flows from October to March and $30 \%$ of the MAR (equivalent to $1.6 \mathrm{~m}^{3} / \mathrm{s}$ ) for the flows from April to September were calculated in this study. Of note is that the $10 \%$ ratio allocated from October to March results in a 6-month critical condition for the river ecosystem; this condition is unacceptable and destructive (i.e., Class F, the worst case as presented in Table 1).

The 7Q10 flow was calculated using daily discharge data from the river. As presented in Table 5, the 7Q10 flow is rated to be as low as $0.1 \mathrm{~m}^{3} / \mathrm{s}$ (i.e., less than $2 \%$ of MAR). This flow rate clearly is far less than any minimum values calculated by alternate predictive methods in Table 5. This method might be compatible with perennial rivers with considerable base flows in humid areas but does not seem to be adapted to rivers with considerable variable flows in cold, semiarid regions, such as the Shahr Chai River.

The EF estimations from the FDCA method are presented in Table 5 for six different percent-of-flow occurrences from 70 to $95 \%$, corresponding to a range from 1.4 to $0.9 \mathrm{~m}^{3} / \mathrm{s}$, respectively. Flows exceeding $90 \%$ of occurrence (i.e., $<$ Q90 \%) are not capable of maintaining basic ecosystem requirements in the river.

\section{Conclusion}

In cases where ecological information is insufficient, hydrological indices can be used to provide an adequate estimation of environmental water requirements in rivers. This study attempts to test several hydrology-based, desktop EFA methods in the context of a developing country (where sufficient data on ecological features and values of rivers are not available), using the Shahr Chai River in Iran as an example. 


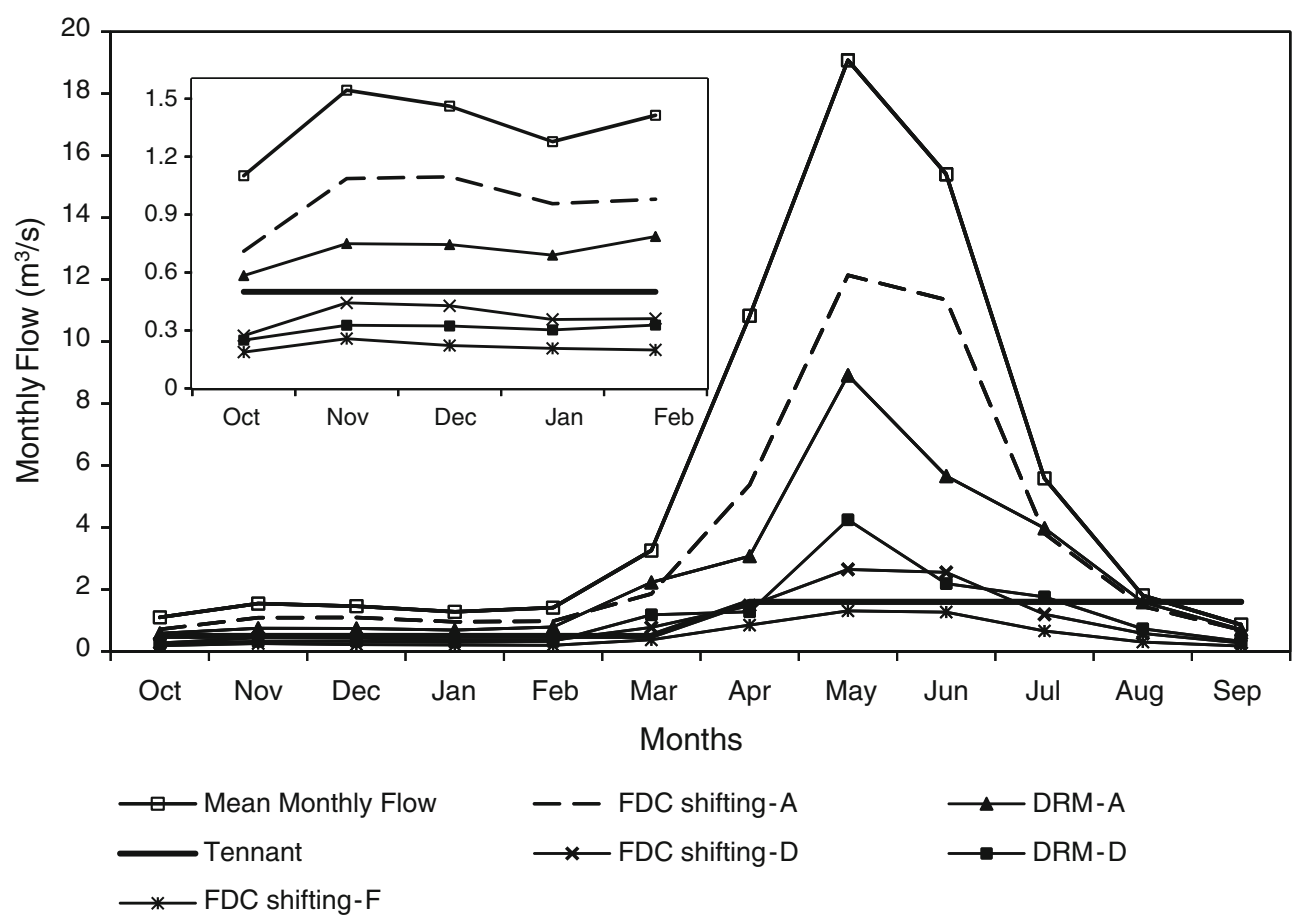

Fig. 5 Comparison of FDC shifting, DRM and Tennant for the Shahr Chai River at the Band Station with months October-February magnified (inset)

Table 5 Estimation of EFs from five hydrological methods, Shahr Chai River

\begin{tabular}{|c|c|c|c|}
\hline \multirow[t]{2}{*}{ Method } & \multicolumn{3}{|c|}{ Environmental water requirement (EWR) } \\
\hline & & (\% of MAR) & $\left(\mathrm{m}^{3} / \mathrm{s}\right)$ \\
\hline \multirow[t]{6}{*}{ FDC shifting } & Class A & 68.8 & 3.6 \\
\hline & Class B & 44.1 & 2.3 \\
\hline & Class C & 28.2 & 1.5 \\
\hline & Class D & 18.9 & 1.0 \\
\hline & Class E & 13.4 & 0.7 \\
\hline & Class F & 10.0 & 0.5 \\
\hline \multirow[t]{4}{*}{ DRM } & Class A & 53.8 & 2.8 \\
\hline & Class B & 35.6 & 1.9 \\
\hline & Class C & 23.2 & 1.2 \\
\hline & Class D & 15.0 & 0.8 \\
\hline \multirow[t]{2}{*}{ Tennant } & Oct-Mar & 10.0 & 0.5 \\
\hline & Apr-Sept & 30.0 & 1.6 \\
\hline 7Q10 & & 1.9 & 0.1 \\
\hline FDCA, Q70 \% & & 26.9 & 1.4 \\
\hline FDCA, Q75 \% & & 25.0 & 1.3 \\
\hline FDCA, Q80 \% & & 23.1 & 1.2 \\
\hline FDCA, Q85 \% & & 22.1 & 1.15 \\
\hline FDCA, Q90 \% & & 19.2 & 1.0 \\
\hline FDCA, Q95 \% & & 17.3 & 0.9 \\
\hline
\end{tabular}

The FDC shifting method developed by Smakhtin and Anputhas (2006) enables rapid estimation of EFRs for different environmental classes if relevant hydrological data (i.e., monthly flow rates) are available. The DRM is a valuable tool for estimating EFRs if quantitative information on the relationships between flow and the ecological 
functioning of the river ecosystem for testing and recalibrating of the model parameters is available. The DRM is capable of adapting any minimum EFRs to prescribed environmental classes. Clearly, corresponding EFs decrease progressively with decreasing levels of ecosystem protection. Alternatives are the generally used hydrological methods (e.g., Tennant, 7Q10, and FDCA), but their outcome flow rates are not directly related to any prescribed ecological preservation levels of a river system.

The predictions of the EF rates for the Shahr Chai River from each of the five methods is compared and presented in Table 5. To maintain the basic function of the river ecosystem, the river should be managed within the Class $\mathrm{C}$ or higher ecological level (as described in Table 1). Comparative results indicate that a minimum flow rate of $1.2 \mathrm{~m} 3 / \mathrm{s}$ (equivalent to $23 \%$ of MAR, or Q80 \% depicted from FDC) is required in the river from the Band gauging station (downstream of the dam) toward Urmia Lake.

The method described in this paper is not an ultimate solution to the problem of EFA. In addition, in the absence of ecological information, desktop EFA methods clearly provide only a low-confidence estimate of EF. The use of such estimates must be supported with knowledge of the ecological functioning of the river system under study. The relationships between flow and ecological condition of the riverine ecosystem must be determined to enhance the quantities of the distributed flow requirements throughout the year and must correspond to prescribed ecological values of the Shahr Chai River and Urmia Lake.

Acknowledgments The authors acknowledge GEFC software that was provided by Nishadi Eriyagama, the International Water Management Institute (IWMI), Colombo, Sri Lanka. The first author also thanks the significant help of Dr. Vladimir Smakhtin for the promotion of the paper quality. The authors would like to thank the comments from anonymous reviewers for improving the paper.

\section{References}

Acreman M, Dunbar MJ (2004) Defining environmental river flow requirements: a review. Hydrol Earth Syst Sci 8(5):861-876

Arthington AH, Rail JL, Kennard MJ, Pusey BJ (2003) Environmental flow requirements of fish in Lesotho Rivers using the DRIFT methodology. River Res Appl 19(5-6):641-666

Chen H, Zhao YW (2011) Evaluating the environmental flows of China's Wolonghu wetland and land use changes using a hydrological model, a water balance model, and remote sensing. Ecol Model 222(2):253-260

Davis R, Hirji R (eds) (2003) Environmental flows: concept and methods. Water Resources and Environment, Technical Note C.1. World Bank, Washington, DC

DWAF (1997) White paper on a National Water Policy for South Africa. Department of Water Affairs and Forestry, Pretoria

Dyson M, Bergkamp G, Scanlon J (2003) The essentials of environmental flows. IUCN, Gland
Hughes DA, Hannart P (2003) A desktop model used to provide an initial estimate of the ecological instream flow requirements of rivers in South Africa. J Hydrol 270(3-4):167-181

Hughes DA, Smakhtin VU (1996) Daily flow time series patching or extension: a spatial interpolation approach based on flow duration curves. Hydrol Sci J 41(6):851-871

IWMI (2004) Environmental flows. Environmental perspectives on river basin management in Asia. vol 1, issue 1. International Water Management Institute, Colombo

Jowett IG (1997) Instream flow methods: a comparison of approaches. Regul Rivers Res Manag 13(2):115-127

Kashaigili JJ, Kadigi RMJ, Lankford BA, Mahoo HF, Mashauri DA (2005) Environmental flows allocation in river basins: exploring allocation challenges and options in the Great Ruaha River catchment in Tanzania. Phys Chem Earth 30(11-16):689-697

Kashaigili JJ, Mccartney M, Mahoo HF (2007) Estimation of environmental flows in the Great Ruaha River Catchment. Tanzania. Phys. Chem. Earth 32(15-16):1007-1014

King J, Brown C (2006) Environmental flows: striking the balance between development and resource protection. Ecol Soc 11(2):26. http://www.ecologyandsociety.org/vol11/iss2/art26/

Lankford BA (2002) Environmental water requirements: a demand management perspective. Water and Environment 17(1):19-22

Lumbroso D (2003) Handbook for the assessment of catchment water demand and use. HR Wallingford, Howbery Park

Naiman RJ, Bunn SE, Nilsson C, Petts GE, Pinay G, Thompson LC (2002) Legitimizing fluvial ecosystems as users of water. Environ Manage 30(4):455-467

Poff NL, Richter BD, Arthington AH, Bunn SE, Naiman RJ, Kendy E, Acreman M, Apse C, Bledsoe BP, Freeman MC, Henriksen J, Jacobson RB, Kennen JG, Merritt DM, O'Keeffe JH, Olden JD, Rogers K, Tharme RE, Warner A (2010) The ecological limits of hydrologic alteration (ELOHA): a new framework for developing regional environmental flow standards. Freshw Biol 55(1):147-170

Powell SL, Letcher RA, Croke BFW (2008) Modeling floodplain inundation for environmental flows: Gwydir wetlands. Aust Ecol Model 211(3-4):350-362

Pyrce R (2004) Hydrological low flow indices and their uses. Watershed Science Centre. WSC Report No. 04, Trent University, Peterborough, Ontario

Richter BD, Baumgartner JV, Powell J, Braun DP (1996) A method for assessing hydrologic alteration within ecosystems. Conserv Biol 10(4): 1163-1174

Richter BD, Baumgartner JV, Wigington R, Braun DP (1997) How much water does a river need? Freshw Biol 37:231-249

Richter BD, Baumgartner JV, Braun DP, Powell J (1998) A spatial assessment of hydrologic alteration within a river network. Regul Rivers Res Manag 14(4):329-340

Smakhtin VU (2001) Low flow hydrology: a review. J Hydrol 240(3-4):147-186

Smakhtin, VU, Revenga C, Doll P (2004) Taking into account environmental water requirements in global scale water resources assessments. Research Report 2 of the CGIAR comprehensive assessment program of water use in agriculture. International Water Management Institute, Colombo

Smakhtin VU, Anputhas M (2006) An assessment of environmental flow requirements of Indian river basins. IWMI Research Report 107. International Water Management Institute, Colombo

Smakhtin VU, Eriyagama N (2008) Developing a software package for global desktop assessment of environmental flows. Environ. Modell. Softw. 23(12):1396-1406

Smakhtin VU, Shilpakar RL, Hughes DA (2006) Hydrology-based assessment of environmental flows: an example from Nepal. Hydrol Sci J 51(2):207-222 
Sun T, Yang ZF, Cui BS (2008) Critical environmental flows to support integrated ecological objectives for the Yellow River Estuary. China Water Resour Manag 22(8):973-989

Tennant DL (1976) Instream flow regimens for fish, wildlife, recreation and related environmental resources. Fisheries 1:6-10

Tharme RE (2003) A global perspective on environmental flow assessment: emerging trends in the development and application of environmental flow methodologies for rivers. River Res Appl 19(5-6):397-441
Tharme RE, Smakhtin VU (2003) Environmental flow assessment in Asia: capitalizing on existing momentum. In: Proceedings of the First Southeast Asia Water Forum, November 2003, Chiang Mai, Thailand. vol 2, pp 301-313. Thailand Water Resources Association, Bangkok

Yang ZF, Sun T, Cui BS, Chen B, Chen GQ (2009) Environmental flow requirements for integrated water resources allocation in the Yellow River Basin. China Commun Nonlin Sci 14(5):2469-2481 